\title{
HYDROACOUSTIC EVALUATION OF THE SPATIAL AND TEMPORAL DISTRIBUTION OF FISH IN THE UPSTREAM PROXIMITY OF A DAM IN A NEOTROPICAL RESERVOIR
}

\author{
Fernanda M. ANDRADE ${ }^{1 *}$, Ivo G. PRADO ${ }^{1,2,3}$, Raquel C. LOURES ${ }^{2}$, \\ Ludimilla P. ZAMBALDI ${ }^{4}$, and Paulo S. POMPEU ${ }^{1}$ \\ ${ }^{1}$ Setor de Ecologia, Departamento de Biologia, Universidade Federal de Lavras, Lavras, Brazil \\ ${ }^{2}$ Programa Peixe Vivo, Cemig Geração e Transmissão, Belo Horizonte, Brazil \\ ${ }^{3}$ Pisces - consultoria e serviços ambientais, Lavras, Brazil \\ ${ }^{4}$ IFMG campus Bambuí, Bambui, Brazil
}

Andrade F.M., Prado I.G., Loures R.C., Zambaldi L.P., Pompeu P.S. 2019. Hydroacoustic evaluation of the spatial and temporal distribution of fish in the upstream proximity of a dam in a Neotropical reservoir. Acta Ichthyol. Piscat. 49 (4): 329-339.

Background. Construction of dams alters the physical, chemical, and ecological characteristics of the aquatic environment and modifies fish behaviour and the community composition. Few studies have shown the diel and seasonal fish distribution in tropical reservoirs, mainly in the proximity of the dam, where the risk of injury and death of fishes, which try to migrate downstream, is high. Thus, the data obtained in these regions can encourage actions that may attenuate the impacts on ichthyofauna. Hydroacoustic sampling is an effective tool to study fish behaviour and their spatial distribution in water bodies. In this context, the aim of this study was to evaluate the spatial and seasonal distribution of fish in the reservoir of Três Marias (Minas Gerais, Brazil), immediately upstream of the dam, using hydroacoustic and gillnet sampling.

Material and methods. Hydroacoustics and gillnet sampling were carried out both during the day and at night, and during the rainy and dry seasons. For the acquisition of hydroacoustic data, we employed an echosounder (BioSonics DT-X Digital Scientific) with a split-beam digital transducer. For the biological data, gillnets of different mesh sizes were set.

Results. Hydroacoustic data showed significant differences in fish depth between day and night surveys, with fish remaining in deeper water during the day, a phenomenon known as Diel Vertical Migration. Furthermore, hydroacoustic data showed that smaller fish (estimated by "target strength") concentrate at smaller depths. There was no significant difference in the size of fish between seasons. Limnological and operation variables were not related to the fish abundance. Distribution maps showed that during the day fishes were distributed in areas more distant from the dam, while at night they were closer to the dam. Gillnets sampled 127 individuals of 22 species and $57.5 \%$ of the collected specimens were migratory species.

Conclusion. These results can contribute to the understanding of fish behaviour in reservoirs, as well as provide an empirical basis for the development of novel fish management measures for Neotropical dams.

Keywords: dam, echo sounding, migratory fish, reservoir ecology, São Francisco River

\section{INTRODUCTION}

Brazil has one of the largest inland water complexes in the world, characterized by the presence of many rivers of substantial length, width, and depth. National energy demands have led to the damming several of Brazilian rivers and the construction of many hydroelectric power plants. Indeed, during the latter half of the 20th century, the construction of reservoirs for energy generation increased considerably in South America (Agostinho et al. 2008). Consequently, the majority of Brazilian rivers and basins are or will be influenced by dams, such as the Amazon River basin, where huge dams have been built and several others are planned to be built in the next few years (Winemiller et al. 2016).

The formation of a storage reservoir, as in the case of Três Marias dam lake in the São Francisco River, modifies the limnological dynamics of the previous lotic environment to lentic one (Agostinho et al. 2008), generating negative impacts both downstream and upstream from the dam. The reduction of water velocity 
leads to higher deposition of organic matter at the bottom of the reservoir, which may reduce the water turbidity and cause instability in benthic communities, influencing the availability of food for fish and to increase the risk of predation. Some areas of the reservoir may still become uninhabitable for some species of fish due to thermal stratification (Agostinho et al. 2007) and others, like areas closer to the dam, to present a high risk of death and injury to fish that try to migrate downstream (Coutant and Whitney 2000).

Fish migration patterns in Neotropical reservoirs are still poorly known. Some phenomena have been described in the literature such as the daily vertical and horizontal migrations, mainly for temperate lakes and reservoirs (Prchalová et al. 2008, Muška et al. 2013). Abiotic and biotic factors such as physical-chemical parameters, habitat complexity, competition, and predation have been suggested as regulators of these behaviours (Fernando and Holcík 1991, Gaudreau and Boisclair 1998). However, little is known about the distribution of fish in Neotropical reservoirs and the knowledge about their distribution can provide information on the factors that can interfere in their feeding, migration, reproduction and growth.

In Brazil, studies on fish distribution in reservoirs show that littoral zones are important areas because they are highly productive environments due to the large input of nutrients and food resources (Agostinho et al. 2007), as well as to spatial heterogeneity due to the presence of wood, aquatic macrophytes, rocks and substrates (AraújoLima et al. 1995). According to Agostinho et al. (2007), the pelagic areas of the reservoir are sparsely populated due to the conditions offered. Considering this scenario, we tested the hypotheses that the littoral zones and regions near tributaries will present higher fish abundances, and vertical migration will produce daily patterns of depth distribution, regardless the season, the dam operation and the variation of the limnological factors.

Hydroacoustics is considered one of the best approaches to describe spatial and temporal distributions of fish species (Simmonds and MacLennan 2005). According to Lucas et al. (2001), despite some limitations, such as the difficulty in taxonomic identification of fishes and impossibility of sampling close to the surface or bottom, which can be compensated with gillnet sampling, this technique is of high value for fish behavioural studies (Brandt 1996, Simmonds and MacLennan 2005). Moreover, it is not an intrusive approach and allows for rapid sampling of the entire water column, thus providing information regarding density, distribution and size of the detected organisms (Simmonds and MacLennan 2005, Parker-Stetter et al. 2009).

In Brazil, relatively few studies have used hydroacoustic data to evaluate fish distribution, and the majority of them have been conducted in marine environments (Sumida et al. 2004, Madureira et al. 2005, Bezerra-Neto et al. 2012). However, considering the studies conducted in freshwater environments (Rotta et al. 2012, Bezerra-Neto et al. 2013, Prado and Pompeu 2014, Loures and Pompeu 2015, Prado and Pompeu 2016), three were from the Três Marias Dam
Reservoir (Prado and Pompeu 2014, Loures and Pompeu 2015, Prado and Pompeu 2016).

Although many ichthyofauna studies have been conducted in reservoirs, data for areas adjacent to the dams are scarce. Considering the impacts caused by the construction of dams and the demand of knowledge about the reservoir fish distribution, the aim of this study was to assess spatial and seasonal variation in the fish distribution in the reservoir of Três Marias Dam, in a stretch immediately upstream of the dam, using hydroacoustics and gillnetting sampling.

\section{MATERIALS AND METHODS}

Study area. This study was conducted at the reservoir of Três Marias Dam (TMR), in the upper São Francisco watershed, located in Minas Gerais state, Brazil $\left(18^{\circ} 12^{\prime} 51^{\prime \prime} \mathrm{S}\right.$ and $\left.045^{\circ} 15^{\prime} 51^{\prime \prime} \mathrm{W}\right)$ (Fig. 1). The TMR was inaugurated in January 1961, to regulate the São Francisco River for multiple purposes including navigation, irrigation, sanitation, and hydroelectricity (Cachapuz 2006).

The dam is $2700 \mathrm{~m}$ in length and $75 \mathrm{~m}$ high, and its reservoir holds a total volume of $19528 \mathrm{hm}^{3}$ (Cachapuz 2006). When the reservoir attains its maximum level, the flooded area corresponds to $1050 \mathrm{~km}^{2}$ and $21 \cdot 10^{9} \mathrm{~m}^{3}$ volume. The maximum depth may exceed $60 \mathrm{~m}$ (Sampaio and López 2003). The plant generation capacity is 396 MW divided into six Kaplan turbines $66 \mathrm{MW}$ each and maximum water discharge of $150 \mathrm{~m}^{3} \cdot \mathrm{s}^{-1}$ each. It has a controlled surface spillway with $8,700 \mathrm{~m}^{3} \cdot \mathrm{s}^{-1}$ maximum capacity (Cachapuz 2006). The reservoir water is classified as warm monomictic (Esteves et al. 1985) and presents thermal stratification during summer. During periods of heavy rain, spillages are common (Prado and Pompeu 2014).

The mean annual rainfall of the region ranges from 1200 to $1300 \mathrm{~mm}$ and the mean temperature is $21.9^{\circ} \mathrm{C}$ (Esteves et al. 1985). There are two well-defined seasons: the rainy period from October to March and the dry period from April to September (Prado and Pompeu 2014). The reservoir water comes mainly from the São Francisco River and some tributaries like São Vicente, Paraopeba, Extrema, Sucuriú, Indaiá, Ribeirão do Boi, and Borrachudo (Esteves et al. 1985).

The maximum and minimum depths observed in the sampled area of the reservoir were $52.07 \mathrm{~m}$ and $5.57 \mathrm{~m}$, respectively (Fig. 1). The deepest region seems to coincide with the former main riverbed of the São Francisco River before the reservoir formation, and at the left bank, the deepest portion seems to be related to the tributary that flowed next to the sampling area, the Borrachudo River (Fig. 1). The water temperature showed a greater variation during the rainy period (February and November) and the dissolved oxygen presented greater variation between day and night in the months of August and November (Table 1), similar data were found by Prado and Pompeu 2016.

Três Marias Dam is a barrier between the middle and upper stretches of the São Francisco River in Minas Gerais State. The reservoir has a considerable number of fish species and at about $8 \%$ of them are migratory, such as Salminus hilarii Valenciennes, 1850; Prochilodus argenteus 


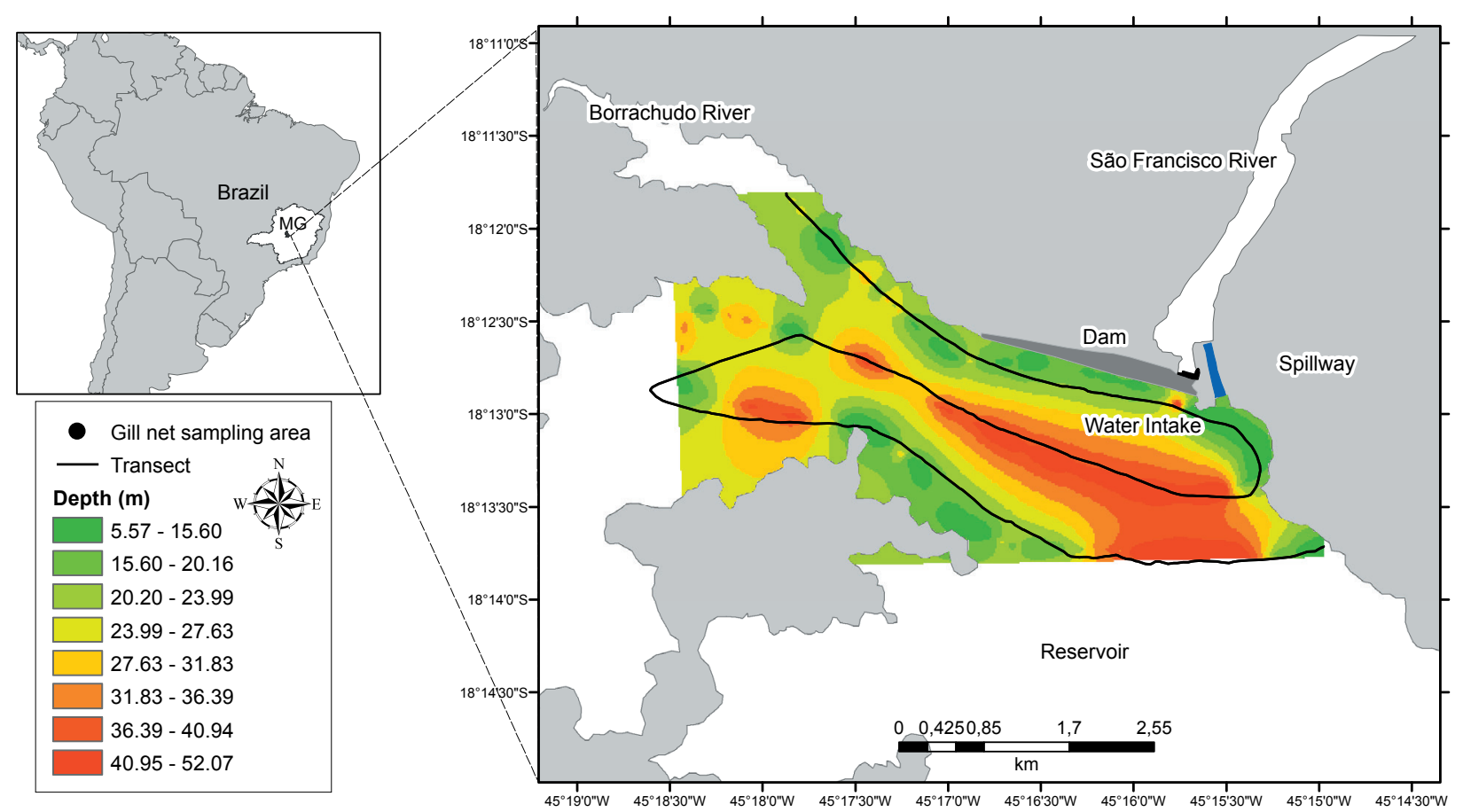

Fig. 1. Sampling area highlighting the transects conducted during hydroacoustic data collection and bathymetric profile of the study area at Três Marias Reservoir, Minas Gerais State, Brazil, in November 2011 when the reservoir level was $565.7 \mathrm{~m}$ above sea level

Table 1

Values of limnological variables for the months of February and November (rainy) and May and August (dry) of 2011, sampled before beginning hydroacoustic data acquisition, in a stretch immediately upstream of Três Marias Dam, Minas Gerais State, Brazil

\begin{tabular}{llccccc}
\hline \multicolumn{1}{c}{ Month } & Period & $\mathrm{pH}$ & $\begin{array}{c}\text { Dissolved oxygen } \\
{\left[\mathrm{mg} \cdot \mathrm{L}^{-1}\right]}\end{array}$ & $\begin{array}{c}\text { Temperature } \\
{\left[{ }^{\circ} \mathrm{C}\right]}\end{array}$ & $\begin{array}{c}\text { Transparency } \\
{[\mathrm{m}]}\end{array}$ & $\begin{array}{c}\text { Turbine flow } \\
{\left[\mathrm{m} \cdot \mathrm{s}^{-1}\right]}\end{array}$ \\
\hline February & Day & 8.04 & 7.63 & 29.40 & 3.02 & 546 \\
May & Day & 7.49 & 5.84 & 25.80 & 2.15 & 464 \\
August & Day & 7.71 & 8.50 & 23.90 & 3.66 & 575 \\
November & Day & 7.97 & 6.93 & 26.0 & 1.95 & 751 \\
February & Night & 8.06 & 7.62 & 30.10 & 3.02 & 546 \\
May & Night & 7.40 & 5.75 & 25.80 & 2.15 & 464 \\
August & Night & 7.52 & 7.10 & 24.98 & 3.66 & 575 \\
November & Night & 6.91 & 8.00 & 24.56 & 2.94 & 751 \\
\hline
\end{tabular}

Spix et Agassiz, 1829; and Pimelodus maculatus Lacepède, 1803 (see Sato and Godinho 2003).

Acoustic data. Hydroacoustic data collections were conducted during the rainy season in February and November, and in the dry season, in May and August of 2011, and pooled per season. Sampling events were conducted during the day (0800) and at night (1800) periods. In each sampling event, three transects, each one about $7 \mathrm{~km}$ long, $400 \mathrm{~m}$ from each other, were conducted, in a small motorboat travelling at a constant speed $(7 \mathrm{~km}$ - $\mathrm{h}^{-1}$ ) across the reservoir immediately upstream from the dam and parallel to it (Fig. 1). The transect closest to the dam was at about $250 \mathrm{~m}$ away. In the other hand, the further one was more than $1 \mathrm{~km}$ away from the dam.

To conduct the samplings transects with the boat at a constant speed of at about $7 \mathrm{~km} \cdot \mathrm{h}^{-1}$ were conducted.
The boat was equipped with a BioSonics DT-X Digital Scientific echosounder (BioSonics Inc., Seattle, Washington, USA), with a split-beam $6^{\circ}$ digital transducer at $123 \mathrm{kHz}$, installed laterally on the boat, and held $0.5 \mathrm{~m}$ below the water surface, oriented vertically towards the reservoir bottom. This orientation is indicated because of the reservoir depth and reverberation that occur when the beam gets to the surface. A Differential Global Positioning System with a highly sensitive 17X NMEA 0183 VHS Garmin antenna was coupled to the system. The Visual Acquisition software (ver. 6.0) was used for visualization, acquisition and data storage (BioSonics Inc.). In the field, the equipment was calibrated using a tungsten carbide sphere before the beginning of the data collection following the procedures recommended by Foote et al. (1987) and BioSonics Inc. 
Sampling design and echosounder configuration parameters were determined and validated in a pilot study that assessed efficiency by the degree of coverage and coefficientofvariation $(<0.25)$, followingrecommendations of Parker-Stetter et al. (2009) and Simmonds and MacLennan (2005). The maximum depth detected in the sampling area during the pilot study was $52.07 \mathrm{~m}$. Based on these results, the parameter configuration was set at 5 pings per second with $0.5 \mathrm{~ms}$ of pulse length, according to Parker-Stetter (2009). An acoustic energy threshold of $-100 \mathrm{~dB}$ was set. Limnological variables, as water temperature and $\mathrm{pH}$, were measured before beginning acoustic data acquisition, to ensure the echosounder was properly set up.

Gillnet sampling. In order to validate the hydroacoustic data (Jurvelius et al. 2011), the collection of fishes in the studied area was performed, thus information on fish species composition and real size of individuals were obtained. The combination of both techniques become the results more reliable (Loures and Pompeu 2015).

Three sets of gillnets, each $10 \mathrm{~m}$ long and $1.6 \mathrm{~m}$ high, of different mesh sizes (stretch mesh) 3, 4, 5, 6, 8, 10, 12,14 , and $16 \mathrm{~cm}$, were used. The nets remained for 24 $\mathrm{h}$ and were checked every $12 \mathrm{~h}$, at 0600 and 1800 . The nets were set in a pelagic region close to the dam (Fig. 1) at three different depths (up to $10 \mathrm{~m}$, between 10 and 30 $\mathrm{m}$ and over $30 \mathrm{~m}$ ) using buoys and fenders. The sampling was conducted one day before the hydroacoustic data collection. Collected fishes were anaesthetized with clove oil, sacrificed, and fixed in $10 \%$ formalin and identified according to Britski et al. 1984. Then the fishes were preserved in $70 \%$ alcohol, and voucher specimens were deposited in the Ichthyological Collection of the Federal University of Lavras (CI-UFLA).

Statistical analyses. Hydroacoustic data were processed in Echoview software, version 4.8 (Echoview Software Pty Ltd., Hobart, Tasmania, Australia). To be considered a fish track, at least three single echoes, from the same target (any object or organism detected in the water column), no more than three pings distance from each other, were required. Near-field and far-field areas were calculated following Parker-Stetter et al. 2009 and were not included for the analysis. Fish tracks were counted (echo counting) to generate abundance estimates since no fish schools were observed. Since a fish presents values of target strength (TS), ranging from $-65 \mathrm{~dB}$ to $-25 \mathrm{~dB}$ (Brandt 1996), the Echoview was set to detect single targets in this range of threshold. TS is a logarithmic measurement of the proportion of energy transmitted by the transducer, which is reflected by the target (Simmonds and MacLennan 2005). For fish, the TS value varies with the size and shape of the swim bladder (Parker-Stetter et al. 2009). Therefore, TS measures can be used as a proxy of fish size (Foote et al. 1987).

The relation between limnological variables and fish abundance were tested by linear regression. The same analysis was performed to test the relation between fish tracks abundance and turbine discharge. During the study, no spill by the dam was observed.
Comparisons between the mean depth (squared root transformed for normalization) of fishes during day and night and between the rainy and dry seasons were conducted through Factorial ANOVA. A $t$-test was used to compare the mean and Kolmogorov-Smirnov test to compare the distribution $s$ of fish TS between seasons. Fish depth distribution was also assessed through histograms of fish track densities per depth classes, considering the projection area of the $6^{\circ}$ wide echosounder beam angle. A simple linear regression was conducted to verify the relation between the fish TS and their respective depth. Such analyses were conducted in the Statistica 10.0 software (Stasoft).

ArcGIS 9.3.1 software was used to interpolate fish track data through the Inverse Distance Weighting (IDW) method, to graphically assess the abundance and location of fishes and verify the reservoir depth. Such analyses are based on spatial dependence, which assumes that the closer one point is to another, the greater the correlation between their values will be. Thus, a higher weight is attributed to the closer samples than to those further from the point to be interpolated. Therefore, the model consists of multiplying the sample values by the inverse of their respective distances for the interpolation of values (Childs 2004). To generate the map of fish distribution, the sampling area was divided into a grid composed of $30 \mathrm{~m}$ by $30 \mathrm{~m}$ cells $\left(900 \mathrm{~m}^{2}\right)$. Once there is no methodology that specifies the exact value to choose cells size, the size was defined through tests, which identify the best scale that incorporated the necessary and appropriate fish records values of the sample points for interpolation analysis and presentation of the results. Each cell resulted in a mean number of fishes detected by the echosounder that was then interpolated to adjacent cells. Furthermore, the reservoir bathymetric map was prepared in the same software using data from hydroacoustic collections conducted in November 2011, when the reservoir level was $565.7 \mathrm{~m}$ above sea level (Fig. 1).

\section{RESULTS}

Concentrated greater abundances of fishes were detected closer to the dam at night, regardless of the season (Fig. 2), while during the day a higher abundance of fishes in the areas distant from the dam and near the Borrachudo River mouth was observed. No significant relation $(P>0.05)$ was found between fish abundance and $\mathrm{pH}(r=-0.37)$, DO $(r=-0.36)$; temperature $(r=0.03)$, transparency $(r=-0.07)$, or turbine discharge $(r=-0.27)$.

Hydroacoustic surveys recorded 16191 fishes, with the majority (58\%) being detected in the rainy season. In relation to the sampling period, a higher number of fishes were recorded at night, especially during the rainy season. In the dry season 3259 fishes were recorded during the day and 3689 at night, while in the rainy season, 3156 fishes were detected during the day and 6087 at night.

Significant differences were observed regarding the fish depth between day and night $\left(F_{1,6877}=9926 ; P<\right.$ $0.01)$ and between rainy and dry seasons $\left(F_{1,143}=206 ; P\right.$ $<0.01)$, as well as when the interaction of both variables 


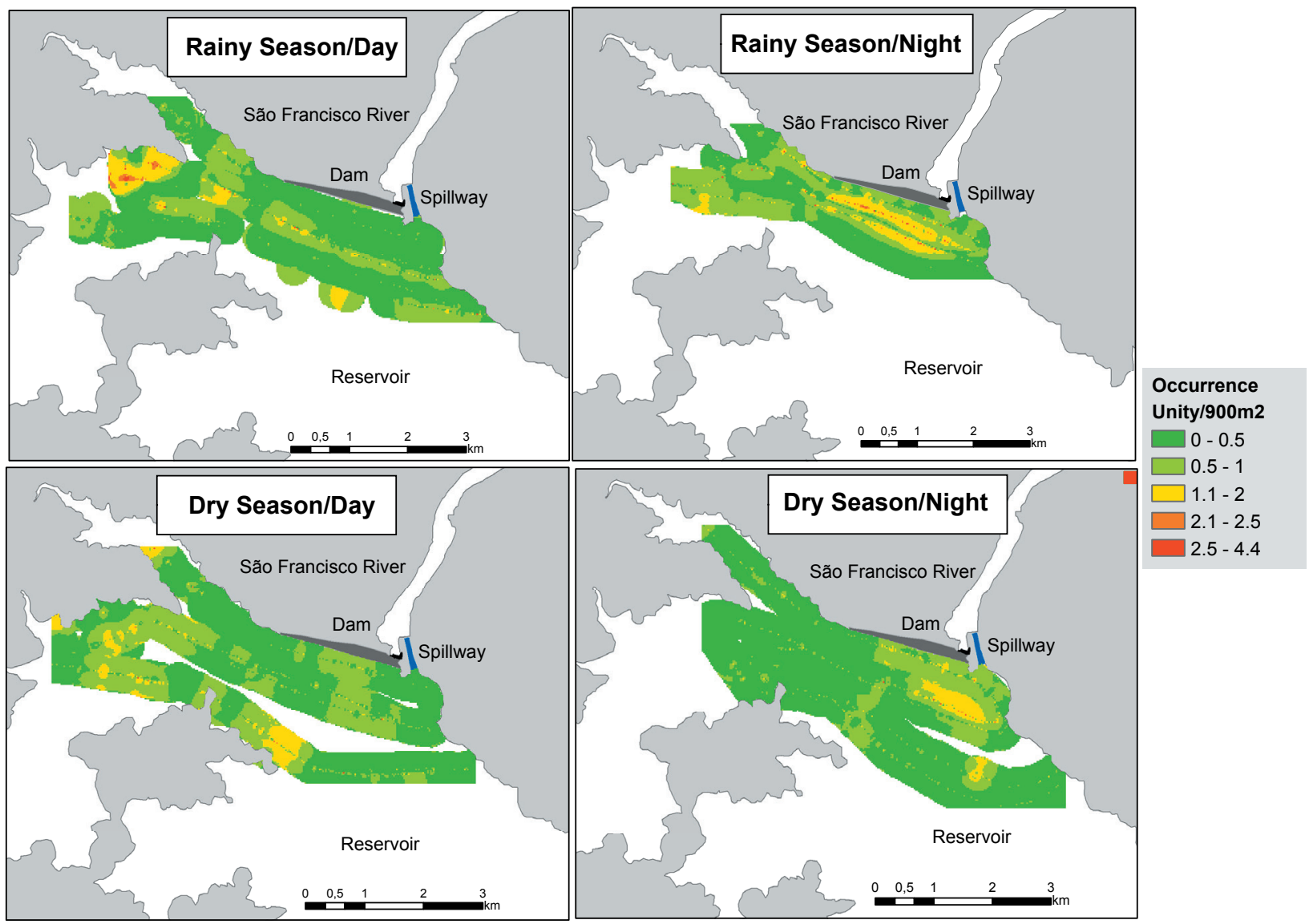

Fig. 2. Fish distribution in Três Marias Reservoir, Minas Gerais State, Brazil, in dry and rainy seasons during day and night samplings; map demonstrate the mean number of fish detected by the echosounder interpolated in cells of $900 \mathrm{~m}^{2}$

was considered $\left(F_{1,120}=174 ; P<0.01\right)$. In both seasons, during the night fish were concentrated close to the surface, while during the day they were found deeper in the reservoir (Fig. 3). Such daily differences in depth were more pronounced during the rainy season when fish were located deeper during the day (Fig. 3).

Most of the fish detected presented TS scores between -60 and $-45 \mathrm{~dB}$, and significant differences in TS mean were not observed between the seasons $\left(F_{1,18}=0.04 ; P\right.$ $=0.83$; Fig. 4). However, the distribution was different $(\mathrm{KS}=22.68 ; P<0.001)$ with a greater number of fishes with low TS values detected in the rainy season compared to the dry season (Fig. 5).

A significant but weak relation $(r=0.40 ; P<0.001)$ between TS and fish depth was observed during the dry season for both day $(r=0.35)$ and night $(r=0.32)$, and also during rainy season for both day $(r=0.42)$ and night $(r=0.24)$ (Fig. 5). In general, the majority of the fish with lower TS were detected in shallower water, and during the night they concentrated closer to the surface. Fish with higher TS values were observed in a greater range of depths in the reservoir.

Gillnet samplings resulted in the collection of 127 individuals belonging to 22 species. The most abundant were Pimelodus maculatus", Leporinus reinhardt,
Hypostomus margaritifer, and Cichla kelberi (Table 2 ). Five of the 22 sampled species were considered migratory (Sato and Godinho 2003) and corresponded to $57.5 \%$ of the total abundance. About $67 \%$ of the total individuals were sampled at night and $68.5 \%$ were sampled in the rainy season (Table 2). Some species were only sampled at night (Eigenmannia virescens, Franciscodoras marmoratus, Hypostomus margaritifer, Leporinus taeniatus, Serrasalmus brandtii, and Triportheus guentheri), while others were only during the day (Astyanax fasciatus, Cichla piquiti, Leporellus vittatus, and Leporinus obtusidens). Still Cichla kelberi, Leporinus reinhardti, and Pimelodus maculatus were sampled in both periods. Eleven species were captured only at the surface gillnet, Astyanax fasciatus only at the intermediate depth and 4 species only at the bottom. Pimelodus maculatus, the most abundant species, were captured at all depths. (Table 2).

\section{DISCUSSION}

The formation of a reservoir leads to severe and irreversible changes in the natural regime of rivers, thus altering habitats and ecosystem functioning in aquatic communities (Agostinho et al. 2008). At the sampled area, fish seemed to prefer regions closer to the Borrachudo 


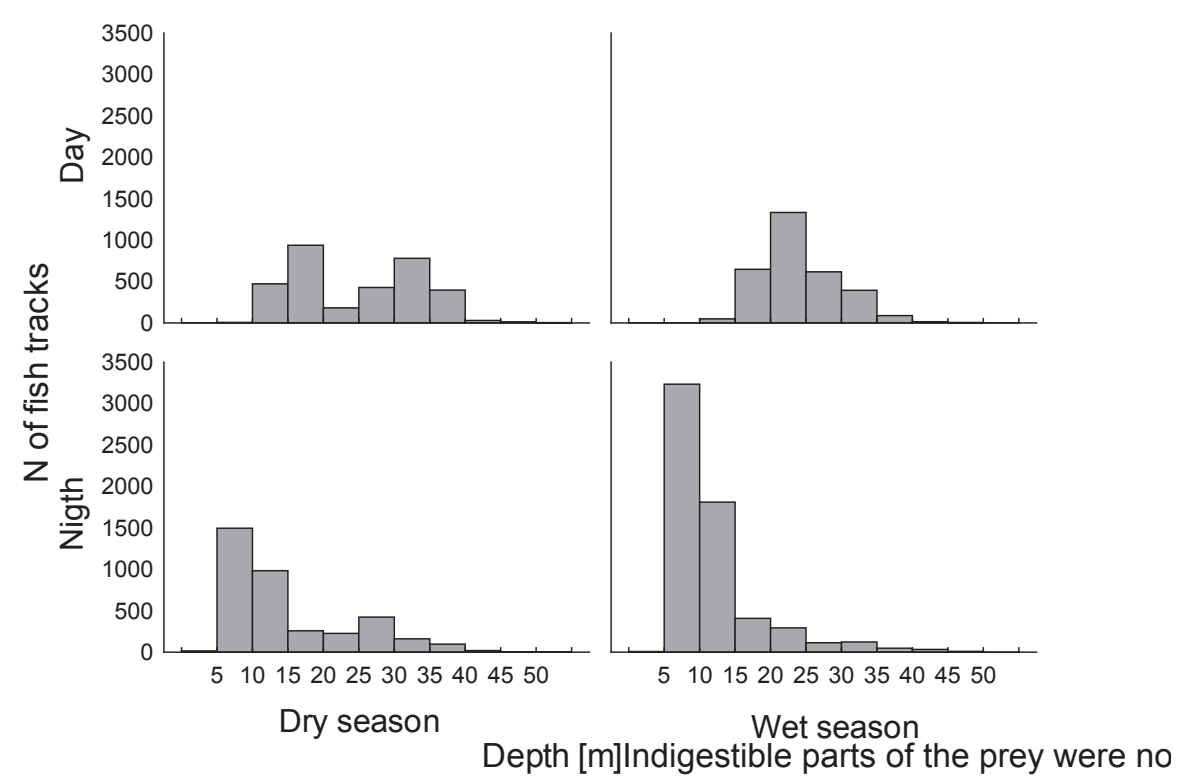

Fig. 3. Density of fish tracks by depth classes, considering the area of the echosounder transducer beam angle $\left(6^{\circ}\right)$, in Três Marias Reservoir, Minas Gerais State, Brazil, during day and night sampling conducted in rainy and dry seasons

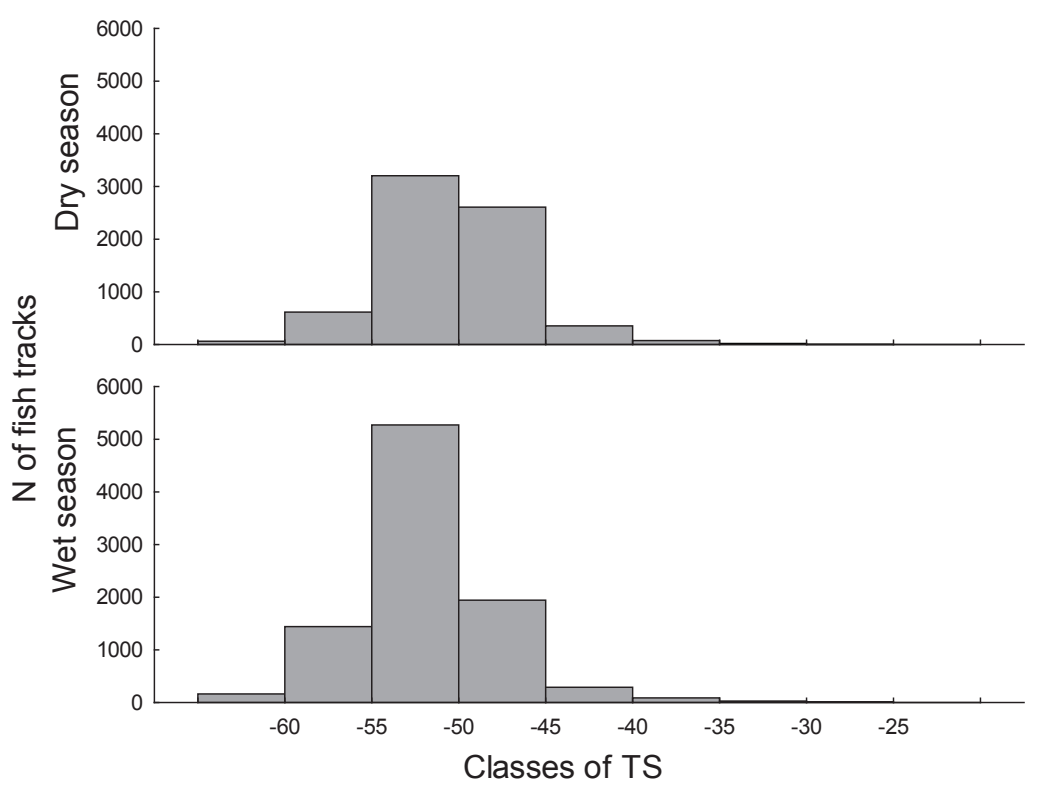

Fig. 4. Number of fish tracks of each TS (target strength) class observed in dry and rainy season in Três Marias Reservoir, Minas Gerais State, Brazil

River mouth as well as areas near the reservoir shore, during the day. A study conducted in Brazilian reservoirs showed that fishes preferred the shore areas, in which the presence of branches, macrophytes, stones, and substrate provide a favourable environment for their vital function (Araújo-Lima et al. 1995). Moreover, these areas represent a highly productive environment due to the high input of nutrients and food resources (Agostinho et al. 2007).

During night time in both rainy and dry seasons, regions closer to the dam presented the greatest abundance of fish. This pattern might be associated to the daily horizontal migration of fish, a behaviour already observed in reservoirs in natural temperate lakes (Gliwicz et al. 2006, Muška et al. 2013) but not yet evidenced in tropical reservoirs. This migration may vary according to the direction (inshore to offshore, or the opposite) (Gliwicz, et al. 2006), ontogeny (Werner and Hall 1988), and according to the size of the lake (Gliwicz, et al. 2006). Abiotic factors such as temperature, dissolved oxygen, and insolation can interfere in these movements (Imbrock et al. 1996, Garner et al. 1998). However, in this study, the analysed limnological variables did not present significant relation with this pattern. Moreover, ecological factors related to feeding and the probability of predation can exert a great influence in this migration (Muška et al. 2013). There may be some unstudied environmental or abiotic factor influencing such behaviour. However, with the data gathered in this study, it was not possible to make any 


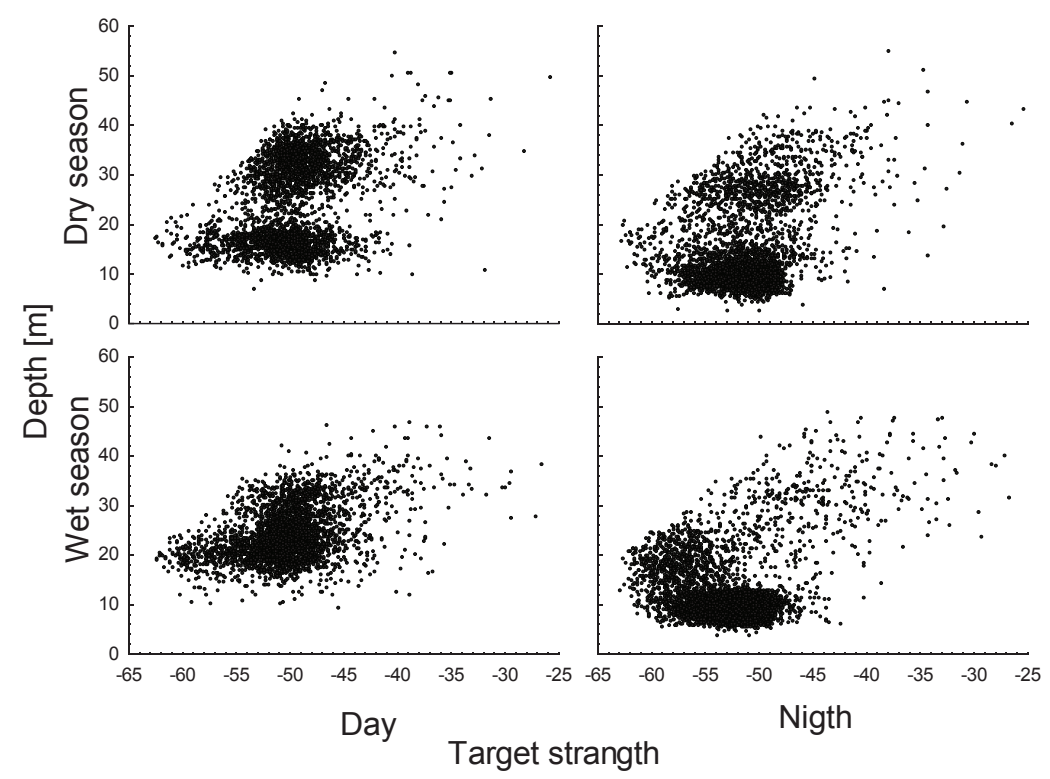

Fig. 5. Correlation between depth and target strength of recorded targets during day and night, in dry and rainy seasons in Três Marias Reservoir, Minas Gerais State, Brazil

assumptions. One hypothesis is the influence of the dam's artificial lights which may influence the attractiveness of fish due to a larger number of preys whether they are other fish or other invertebrate organisms, but a specific study is required to explicitly test this hypothesis.

The daily variation in the depth that fish were detected in both seasons, deeper portions during the day and shallower portions at night, characterizes the phenomenon known as the Diel Vertical Migration (DVM) (Mehner et al. 2007). Opportunities for food, escaping from predators and bioenergetics efficiency may explain the occurrence of such behaviour (Mehner et al. 2007), as well as limnological characteristics like light penetration (Matthews 1998), temperature (Magnuson et al. 1979), dissolved oxygen (Prado and Pompeu 2016), and pH (Jones et al. 1985). Few studies carried out in Brazil have observed DVM and the majority of them were related to zooplanktonic communities (Bezerra-Neto et al. 2009, Silva et al. 2009, Ghidini and Santos-Silva 2011). Only two studies have identified this phenomenon in fish assemblages, Picapedra et al. (2015) in lakes in Mato Grosso do Sul state and Prado and Pompeu (2016), also in the TMR. The study of Picapedra et al. (2015) evidences the feeding preference of fish larvae during the night, a favourable period to visualize their prey on the surface, and stayed in deeper portions during the day as a protection strategy against predation. According to Mehner (2012), the abundance of zooplankton available for fish feeding is higher at night, which leads to higher feeding rates in this period. On the other hand, the study conducted by Prado and Pompeu (2016) showed that limnological variables such as dissolved oxygen and water transparency were related to DVM. However, the authors did not find a significant relation between the variables related to the operations of the dam and fish distribution, a result also found in this study. This shows that both biotic and abiotic factors can influence the fish DVM.
A significant relation was observed between TS of fishes (proxy of body size) and the depth they were detected during the day and night in both seasons. Interactions between biotic and abiotic factors determine the composition and structure of fish communities (Jackson et al. 2001). However, predation is known as one of the most important factors influencing community structure (Zaret 1972). Predators in general, but mainly piscivores, may be influenced by prey spatial distribution and behaviour (Oliveira and Goulart 2000). Preys are usually found in darker habitats during the day to avoid predators (Clark and Levy 1988), thus, generally found in deeper regions. Therefore, smaller fish (lower TS) tend to aggregate in order to be protected from predation, or for feeding and reproductive strategies, as observed in the presently reported study, whereas larger fishes (higher TS) were found to be more randomly distributed throughout the water column. However, no schools were detected in this study.

The hypothesis that there is vertical variation in the distribution of the fish immediately upstream of the Três Marias Dam, between the diurnal and nocturnal periods and rainy and dry seasons, was confirmed with the presented data. However, the factors that explain such variation are still to be elucidated. In Três Marias Reservoir, the presence of some piscivorous species was confirmed with gillnet sampling such as Salminus hilarii, Serrasalmus brandtii, Cichla kelberi, and Cichla piquiti (Table 2). This may indicate that predator-prey interactions may have an important influence on the fish distribution of this reservoir, which corroborates with the hypothesis that ecological interactions, mainly between predator-prey, in general play a fundamental role in the distribution of fish in reservoirs (Zaret 1972, Oliveira and Goulart 2000, Picapedra et al. 2015).

Studies on fish behaviour, such as their temporal and spatial distribution, are essential for the implementation 
Table 2

Diel and seasonal changes in the number of fish individuals detected in the Três Marias Dam Reservoir, Brazil

\begin{tabular}{|c|c|c|c|c|c|c|c|c|c|}
\hline \multirow{2}{*}{ Taxon } & \multirow{2}{*}{$\mathrm{COM}$} & \multicolumn{5}{|c|}{$N$} & \multirow{2}{*}{ Depth } & \multicolumn{2}{|c|}{ Exp. TS $[\mathrm{dB}]$} \\
\hline & & Day & Night & Rainy & Dry & Total & & Min & Max \\
\hline \multicolumn{10}{|l|}{ Engraulidae } \\
\hline Anchoviella vaillanti (Steindachner, 1908) & & - & 1 & - & 1 & 1 & $\mathrm{~s}$ & -55.0 & - \\
\hline \multicolumn{10}{|l|}{ Acestrorhynchidae } \\
\hline Acestrorhynchus lacustris (Lütken, 1875) & & - & 1 & - & 1 & 1 & $\mathrm{~s}$ & -49.6 & - \\
\hline \multicolumn{10}{|l|}{ Anostomidae } \\
\hline Leporellus vittatus (Valenciennes, 1850) & & 1 & - & 1 & - & 1 & $\mathrm{~s}$ & -45.9 & - \\
\hline Leporinus obtusidens (Valenciennes, 1837) & M & 1 & - & - & 1 & 1 & $\mathrm{~s}$ & -44.0 & - \\
\hline Leporinus reinhardti Lütken, 1875 & M & 2 & 16 & 14 & 4 & 18 & $\mathrm{~s}, \mathrm{i}$ & -52.8 & -42.4 \\
\hline Leporinus taeniatus Lütken, 1875 & M & - & 3 & 3 & - & 3 & $\mathrm{~s}$ & -49.6 & -46.8 \\
\hline Schizodon knerii (Steindachner, 1875) & & 1 & 3 & 2 & 2 & 4 & s & -50.3 & -40.5 \\
\hline \multicolumn{10}{|l|}{ Characidae } \\
\hline Astyanax fasciatus (Cuvier, 1819) & & 1 & - & 1 & - & 1 & $\mathrm{i}$ & -49.0 & - \\
\hline Pygocentrus piraya (Cuvier, 1819) & & - & 1 & - & 1 & 1 & $\mathrm{~s}$ & -41.6 & - \\
\hline Salminus hilarii Valenciennes, 1850 & M & 3 & 4 & 5 & 2 & 7 & $\mathrm{~s}, \mathrm{i}$ & -43.1 & -40.7 \\
\hline Serrasalmus brandtii Lütken, 1875 & & - & 7 & 6 & 1 & 7 & $\mathrm{~s}, \mathrm{i}$ & -56.9 & -43.1 \\
\hline Triportheus guentheri (Garman, 1890) & & - & 3 & 3 & - & 3 & $\mathrm{~s}$ & -52.8 & -50.3 \\
\hline \multicolumn{10}{|l|}{ Erythrinidae } \\
\hline Hoplias intermedius (Günther, 1864) & & 1 & 3 & 3 & 1 & 4 & s & -43.2 & -39.0 \\
\hline \multicolumn{10}{|l|}{ Cichlidae } \\
\hline Cichla kelberi Kullander et Ferreira, 2006 & $\mathrm{E}$ & 4 & 4 & 4 & 4 & 8 & s & -45.1 & -35.9 \\
\hline Cichla piquiti Kullander et Ferreira, 2006 & $\mathrm{E}$ & 1 & - & 1 & - & 1 & $\mathrm{~b}$ & -42.1 & - \\
\hline \multicolumn{10}{|l|}{ Sternopygidae } \\
\hline Eigenmannia virescens (Valenciennes, 1836) & & - & 1 & - & 1 & 1 & s & -46.8 & - \\
\hline \multicolumn{10}{|l|}{ Doradidae } \\
\hline Franciscodoras marmoratus (Lütken, 1874) & & - & 1 & 1 & - & 1 & $\mathrm{~b}$ & -44.7 & - \\
\hline \multicolumn{10}{|l|}{ Loricariidae } \\
\hline Hypostomus margaritifer (Regan, 1908) & & - & 10 & 10 & - & 10 & s & -45.3 & -42.0 \\
\hline \multicolumn{10}{|l|}{ Pimelodidae } \\
\hline Bergiaria westermanni (Lütken, 1874) & & 4 & 1 & 1 & 4 & 5 & $\mathrm{~b}$ & -48.4 & -45.5 \\
\hline Pimelodus fur (Lütken, 1874) & & 3 & 1 & 3 & 1 & 4 & $\mathrm{~b}$ & -50.3 & -45.6 \\
\hline Pimelodus maculatus Lacepède, 1803 & M & 20 & 24 & 26 & 18 & 44 & $\mathrm{~s}, \mathrm{i}, \mathrm{b}$ & -51.9 & -40.4 \\
\hline Pimelodus pohli Ribeiro et Lucena, 2006 & & - & 1 & 1 & - & 1 & $\mathrm{~s}$ & -48.4 & - \\
\hline Total & & 42 & 85 & 85 & 42 & 127 & - & -56.9 & -35.9 \\
\hline
\end{tabular}

$\mathrm{COM}=$ comments, $\mathrm{M}=$ migratory species, $\mathrm{E}=$ non-native species; $N=$ number of fish specimens collected, Exp. TS = expected target strength; Depth $=$ depth where fish were caught, $\mathrm{s}=$ surface, $\mathrm{i}=$ intermediate, $\mathrm{b}=$ bottom; the expected target strength of fish was determined according to minimum and maximum size of the individuals.

of fish passage facilities, especially considering the downstream stretches of the river. Furthermore, this study movement from upstream to downstream in dammed confirmed the presence of several migratory species in rivers. The hydroacoustic methods used in the presently the reservoir, reinforcing the need for future studies to reported study were efficient in collecting spatial and evaluate the existence and the extent of migratory fish temporal data on fish distributions. Considering the results of the presently reported study, and the ones presented by Prado and Pompeu (2014), it is plausible to suggest that the passage of migratory fishes by spillways may be possible at night, as fishes prefer shallower regions of the water column, closer to the dam. This could improve or allow the efficiency of downstream fish passage (if present at the dam), and reduce the risk of fish passage through the turbines. Besides, this alternative route would represent lower cost and labour since no structural change (only operational and legal) would be necessary (Larinier 2008). However, the presence and density of non-native species should also be considered, since it could affect passage through the dam.

The use of echosounder in fish distribution studies revealed behavioural patterns over time and space. The preferential habitat, which can vary daily and/or seasonally, can indicate some structuring factors of the fish distribution in the reservoir, such as predation. The fish movements (vertical and horizontal) in the reservoir showed in this study, added to the gillnet sampling information, may help to answer some important questions about the preferential habitat in which some species may be inserted (such as migratory and non-native ones). However, to identify the factors that influence the distribution and behaviour of fish in reservoirs, studies considering complementary limnological data and 
studies on trophic evaluation of fish populations within the reservoir are required. In addition, to use the hydroacoustic technique associated to other techniques such as fish tagging, eDNA, and gillnetting sampling may provide important information about fish distribution for planning actions that mitigate some dam impacts, as well as for improving ichthyofauna monitoring strategies in reservoirs.

\section{ACKNOWLEDGEMENTS}

We are grateful to the Peixe Vivo Program from CEMIG GT for the financial support for the project, to Ruanny Casarim for all support since the beginning of the project until the conclusion of this paper and to Felipe Prado for helping drawing the figures. PSP received a research fellowship from the Conselho Nacional de Desenvolvimento Científico e Tecnológico (CNPq No. 304002/2014-3) and the Fundação de Amparo à Pesquisa do Estado de Minas Gerais (FAPEMIG No. PPM00608/15).

\section{REFERENCES}

Agostinho A.A., Gomes L.C., Pelicice F.M. 2007. Ecologia e manejo de recursos pesqueiros em reservatórios do Brasil. [Ecology and management of fishing resources in Brazilian reservoirs.] Editora da Universidade Estadual de Maringá, Maringá, Brazil. [In Portuguese.]

Agostinho A.A., Pelicice F.M., Gomes L.C. 2008. Dams and the fish fauna of the Neotropical region: Impacts and management related to diversity and fisheries. Brazilian Journal of Biology 68 (4): 1119-1132. DOI: 10.1590/S1519-69842008000500019

Araújo-Lima C.A.R.M., Agostinho A.A., Fabre N.N. 1995. Trophic aspects of fish communities in Brazilian rivers and reservoirs. Pp. 105-136. In: Tundisi J.G., Bicudo C.E.M., Matsumura-Tundisi T. (eds.) Limnology in Brazil. Brazilian Academy of Sciences/ Brazilian Limnological Society, São Paulo, Brazil.

Bezerra-Neto J.F., Brighenti L.S., Mello N.A.S.T., Pinto-Coelho R.M. 2012. Hydroacoustic assessment of fish and Chaoborus (Diptera-Chaoboridae) distribution in three Neotropical lakes. Acta Limnologica Brasiliensia 24 (1): 18-28. DOI: 10.1590/ S2179-975X2012005000023

Bezerra-Neto J.F., Brighenti L.S., Pinto-Coelho R.M. 2013. Implementation of hydroacoustic for a rapid assessment of fish spatial distribution at a Brazilian Lake - Lagoa Santa, MG. Acta Limnologica Brasiliensia 25 (1): 91-98. DOI: 10.1590/S2179975X2013000100010

Bezerra-Neto J.F., Mello N.A.S.T., Maia-Barbosa P.M., Pinto-Coelho R.M. 2009. The role of predation in the diel vertical migration of zooplankton in two tropical freshwaters ecosystems. Acta Limnologica Brasiliensia 21 (1): 45-569.

Brandt S.B. 1996. Acoustic assessment of fish abundance and distribution. Pp. 385-419. In: Murphy R.B., Willis D.W. (eds.) Fisheries techniques. American Fishes Society, Bethesda MD, USA.
Britski H.A., Sato Y., Rosa A.B. 1984. Manual de identificação de peixes da região de Três Marias: com chave de identificação para os peixes da bacia do rio São Francisco. [Fish Identification Manual of the Três Marias region: With an identification key for fish from the São Francisco River Basin.] Codevasf, Brasília. [In Portuguese.]

Cachapuz P.B.B. 2006. Usinas da Cemig: a história da eletricidade em Minas e no Brasil, 1952-2005. [Cemig power plants: The history of electricity in Minas and Brazil, 1952-2005.] Centro da Memória da Eletricidade no Brasil, Rio de Janeiro, Brazil. [In Portuguese.]

Childs C. 2004. Interpolating surfaces in ArcGIS Spatial Analyst. ArcUser July-September 2004: 32-35.

Clark C.W., Levy D.A. 1988. Diel vertical migrations by juvenile sockeye salmon and the antipredation window. The American Naturalist 131 (2): 271-290. DOI: $10.1086 / 284789$

Coutant C.C., Whitney R.R. 2000. Fish behavior in relation to passage through hydropower turbines: A review. Transactions of the American Fisheries Society 129 (2): 351-380. DOI: $10.1577 /$ 1548-8659(2000)129<0351:FBIRTP >2.0.CO;2

Esteves F.A., Amorim J.C., Cardoso E.L., Barbosa F.A.R. 1985. Caracterização limnológica preliminar da Represa de Três Marias (MG) com base em alguns parâmetros ambientais básicos. [Preliminary limnological characterization of the Três Marias Dam (MG) based on some basic environmental parameters.] Ciência e Cultura 37 (4): 608-617. [In Portuguese.]

Fernando C.H., Holčík J. 1991. Fish in reservoirs. Internationale Revue der gesamten Hydrobiologie und Hydrographie 76 (2): 149-167. DOI: 10.1002/ iroh.19910760202

Foote K.G., Knudsen H.P., Vestnes G., MacLennan D.N., Simmonds E.J. 1987. Calibration of acoustic instruments for fish density estimation: A practical guide. Cooperate Research Report No. 144. ICES, Copenhagen.

Garner P., Clough S., Griffiths S., Deans D., Ibbotson A. 1998. Use of shallow marginal habitat by Phoxinus phoxinus: a trade-off between temperature and food? Journal of Fish Biology 52 (3): 600-609. DOI: 10.1111/j.1095-8649.1998.tb02020.x

Gaudreau N., Boisclair D. 1998. The influence of spatial heterogeneity on the study of fish horizontal daily migration. Fisheries Research 35 (1-2): 65-73. DOI: 10.1016/S0165-7836(98)00060-5

Ghidini A.R., Santos-Silva E.N. 2011. Composition, species richness and patterns of nycthemeral vertical distribution of planktonic cladocerans in a black water Amazonian lake. Nauplius 19 (2): 109-122. DOI: 10.1590/S0104-64972011000200002

Gliwicz M.Z., Slon J., Szynkarczyk I. 2006. Trading safety for food: Evidence from gut contents in roach and bleak captured at different distances offshore from their daytime littoral refuge. Freshwater Biology 51 (5): 823-839. DOI: 10.1111/j.1365-2427.2006.01530.x 
Imbrock F., Appenzeller A., Eckmann R. 1996. Diel and seasonal distribution of perch in Lake Constance: A hydroacoustic study and in situ observations. Journal of Fish Biology 49 (1): 1-13. DOI: 10.1111/j.10958649.1996.tb00001.x

Jackson J.B.C., Kirby M.X., Berger W.H., Bjorndal K.A., Botsford L.W., Bourque B.J., Bradbury R.H., Cooke R., Erlandson J., Estes J.A., Hughes T.P., Kidwell S., Lange C.B., Lenihan H.S., Pandolfi J.M., Peterson C.H., Steneck R.S., Tegner M.J., Warner R.R. 2001. Historical overfishing and the recent collapse of coastal ecosystems. Science 293 (5530): 629-637. DOI: 10.1126/science.1059199

Jones K.A., Hara T.J., Scherer E. 1985. Behavioral modifications in Artic char (Salvelinus alpinus) chronically exposed to sublethal $\mathrm{pH}$. Physiological Zoology 58 (4): 400-412.

Jurvelius J., Kolari I., Leskelä A. 2011. Quality and status of fish stocks in lakes: Gillnetting, seining, trawling and hydroacoustics as sampling methods. Hydrobiologia 660 (1): 29-36. DOI: 10.1007/s10750010-0385-6

Larinier M. 2008. Fish passage experience at small-scale hydroelectric power plants in France. Hydrobiologia 609 (1): 97-108. DOI: 10.1007/s10750-008-9398-9

Loures R.C.F., Pompeu P.S. 2015. Seasonal and diel changes in fish distribution in a tropical hydropower plant tailrace: Evidence from hydroacoustic and gillnet sampling. Fisheries Management and Ecology 22 (3): 185-196. DOI: 10.1111/fme.12116

Lucas M.C., Baras E., Thom T., Slavík O. 2001. Migration of freshwater fishes. Blackwell Science. DOI: 10.1002/9780470999653

Madureira L.S.P., Habiaga R., Soares C., Weigert S., Ferreira C., Eliseire D., Duvoisin A.C. 2005. Identification of acoustic records of the Argentinian calamar Illex argentinus (Castellanos, 1960) along the outer shelf and shelf break of the south and southeast coast of Brazil. Fisheries Research 73 (1-2): 251-257. DOI: 10.1016/j.fishres.2005.01.021

Magnuson J.J., Crowder L.B., Medvick P.A. 1979. Temperature as an ecological resource. American Zoologist 19 (1): 331-343. DOI: 10.1093/icb/19.1.331

Matthews W.J. 1998. Patterns in freshwater fish ecology. Springer Science + Business Media, Dordrecht, The Netherlands.

Mehner T. 2012. Diel vertical migration of freshwater fishes-Proximate triggers, ultimate causes and research perspectives. Freshwater Biology 57 (7): 1342-1359. DOI: 10.1111/j.1365-2427.2012.02811.x

Mehner T., Kasprzak P., Hölker F. 2007. Exploring ultimate hypotheses to predict diel vertical migrations in coregonid fish. Canadian Journal of Fisheries and Aquatic Sciences 64 (6): 874-886. DOI: 10.1139/ f07-067

Muška M., Tušer M., Frouzová J., Draštík V., Čech M., Jůza T., Kratochvíl M., Mrkvička T., Peterka J., Prchalová M., Ř́ha M., Vašek M., Kubečka J. 2013. To migrate, or not to migrate: Partial diel horizontal migration of fish in a temperate freshwater reservoir. Hydrobiologia 707 (1): 17-28. DOI: 10.1007/s10750012-1401-9

Oliveira E.F., Goulart E. 2000. Distribuição espacial de peixes em ambientes lênticos: interação de fatores. [Spatial distribution of fishes in lentic environments: factors interaction.] Acta Scientiarum 22 (2): 445-453. [In Portuguese.]

Parker-Stetter S.L., Rudstam L.G., Sullivan P.J., Warner D.M. 2009. Standard operating procedures for fisheries acoustic surveys in Great Lakes. Special Publication 09-01, Great Lakes Fishery Commission, Ann Arbor MI, USA.

Picapedra P.H.S., Lansac-Tôha F.A., Bialetzki A. 2015. Diel vertical migration and spatial overlap between fish larvae and zooplankton in two tropical lakes, Brazil. Brazilian Journal of Biology 75 (2): 352-361. DOI: 10.1590/1519-6984.13213

Prado I.G., Pompeu P.S. 2014. Vertical and seasonal distribution of fish in Três Marias reservoir. Lake and Reservoir Management 30 (4): 393-404. DOI: 10.1080/10402381.2014.955221

Prado I.G., Pompeu P.S. 2016. Diel vertical migration of fish in a Neotropical reservoir. Marine and Freshwater Research 68 (6): 1070-1078. DOI: 10.1071/MF16009

Prchalová M., Kubečka J., Vašek M., Peterka J., Sed'a J., Jůza T., Říha M., Jarolím O., Tušer M., Kratochvíl M., Čech M., Draštík V., Frouzová J., Hohausová E. 2008. Distribution patterns of fishes in a canyon-shaped reservoir. Journal of Fish Biology 73 (1): 54-78. DOI: 10.1111/j.1095-8649.2008.01906.x

Rotta L.H.S., Imai N.N., Batista L.F.A., Boschi L.S., Galo M.L.B.T., Velini E.D. 2012. Sensoriamento remoto hidroacústico no mapeamento de macrófitas aquáticas submersas. [Hydro-acoustic remote sensing in submerged aquatic macrophyte mapping] Planta Daninha 30 (2): 229-239. [In Portuguese.] DOI: 10.1590/S0100-83582012000200001

Sampaio E.V., López C.M. 2003. Limnologias física, química e biológica da represa de Três Marias e do São Francisco. [Physical, chemical and biological limnological parameters of Três Marias and São Francisco dam reservoirs.] Pp. 71-92. In: Godinho H.P., Godinho A.L. (eds.) Águas, peixes e pescadores do São Francisco das Minas Gerais. [Waters, fish, and fishermen from São Francisco das Minas Gerais.] PUC Minas, Belo Horizonte, Brazil. [In Portuguese.]

Sato Y., Godinho H.P. 2003. [5] Migratory fishes of the São Francisco River. Pp: 195-232. In: Carolsfeld J., Harvey B., Ross C., Baer A. (eds.) Migratory fishes of South America: Biology, fisheries, and conservation Status. World Fisheries Trust, World Bank, IDRC.

Silva A.M.A., Medeiros P.R., Silva M.B.C., Barbosa J.E.L. 2009. Diel vertical migration and distribution of zooplankton in a tropical Brazilian reservoir. Biotemas 22(1):49-57.DOI: 10.5007/2175-7925.2009v22n1p49 Simmonds E.J., MacLennan D.N. 2005. Fisheries acoustics: Theory and practice. 2nd edn. Blackwell Science. DOI: 10.1002/9780470995303 
Sumida P.Y.G., Yoshinaga M.Y., Madureira L.A.S.-P., Hovland M. 2004. Seabed pockmarks associated with deepwater corals off SE Brazilian continental slope, Santos Basin. Marine Geology 207 (1-4): 159-167. DOI: 10.1016/j.margeo.2004.03.006

Werner E., Hall D. 1988. Ontogenetic habitat shifts in bluegill: The foraging rate-predation risk trade-off. Ecology 69 (5): 1352-1366. DOI: 10.2307/1941633

Winemiller K.O., McIntyre P.B., Castello L., FluetChouinard E., Giarrizzo T., Nam S., Baird I.G., Darwall W., Lujan N.K., Harrison I., Stiassny M.L.J., Silvano R.A.M., Fitzgerald D.B., Pelicice F.M., Agostinho A.A., Gomes L.C., Albert J.S.,
Baran E., Petrere M.jr., Zarfl C., Mulligan M., Sullivan J.P., Arantes C.C., Sousa L.M., Koning A.A., Hoeinghaus D.J., Sabaj M., Lundberg J.G., Armbruster J., Thieme M.L., Petry P., Zuanon J., Torente Vilara G., Snoeks J., Ou C., Rainboth W., Pavanelli C.S., Akama A., van Soesbergen A., Sáenz L. 2016. Balancing hydropower and biodiversity in the Amazon, Congo, and Mekong. Science 351 (6269): 128-129. DOI: 10.1126/science.aac7082

Zaret T.M. 1972. Predator-prey interaction in a tropical lacustrine ecosystem. Ecology 53 (2): 248-257. DOI: $10.2307 / 1934078$

Received: 21 September 2018 Accepted: 28 May 2019 Published electronically: 15 December 2019 